\title{
Characterization of a hydrolyzed oil obtained from fish waste for nutraceutical application
}

\author{
Vera Lúcia Viana do NASCIMENTO ${ }^{1 \star}$, Victória Maura Silva BERMÚDEZ ${ }^{1}$, André Luis Lima de OLIVEIRA ${ }^{1}$, \\ Maurício Nunes KLEINBERG ${ }^{1}$, Rayane de Tasso Moreira RIBEIRO ${ }^{1}$, Rosa Ferreira Araujo de ABREU², \\ José Osvaldo Beserra CARIOCA ${ }^{1}$
}

\begin{abstract}
The fish industry generates high volume of waste from fish oil that can have the extraction of its lipids used as nutraceuticals and foods. The objective of this study was to produce unsaturated fatty acids from industrialized fish oil by means of a differentiated hydrolysis process. The samples used were crude fish oil obtained from Campestre industry and characterized through physicalchemical parameters, according to AOCS: acidity, peroxide, saponification, iodine and percentage of free fatty acids and also obtained the fatty acid profile through derivatization method for gas chromatography. The results obtained for the oleochemical indices for refined oil were similar to the data found on the literature. The content of polyunsaturated fatty acids (PUFA) was found of 32,78\%, with $9,12 \%$ of docosahexaenoic (DHA) and 10,36\% of eicosapentaenoic (EPA), regarding monounsaturated fatty acids (MUFA) content was of 30,59\% in the hydrolyzed fish oil in relation to refined (20,06\%). Thus, it can be concluded that the hydrolysis process used for oils from fish-waste was satisfactory on the production of absolute yield of lipids in the process and significant preservation on the percentages of EPA and DHA, interesting on the production of nutraceuticals and nutrition of aquatic animals, including shrimp in captivity.
\end{abstract}

Keywords: chemical hydrolysis; polyunsturated fatty acids; nutraceuticals uses.

Practical Application: The production of EPA and DHA concentrates from residual sources of marine oils obtained from discarded parts of fish processing have unexplored potential of use in food industry and oil based nutraceutical production for obtaining the health benefits can be achieved. The economic activities of fish residues can reduce inappropriate extractive fishing, reducing imports of fish oils while contributing to the ecosystem balance.

\section{Introduction}

Currently, fish residues have been used by processing industries for the production of fishmeal and fish oil for the preparation of supplemented foods and pharmaceuticals. The recovery of the residues for this order contributes to the reduction of environmental pollution (Benites \& Souza-Soares, 2010).

The seafood industry has a vast potential for waste generation, including fish oils. An excessive amount of lipid derived from guts, heads, fins, scales and fish skins can be used for development of nutraceutical and food industries. The main source of these fatty acids are cold water fish (Chowdhury et al., 2012), which are sources of eicosapentaenoic (EPA) and docosahexaenoic (DHA), as an example we can cite the sardines, mackerel and anchovies (Corrêa, 2008).

Fish are rich in essential fatty acids, among which the long chain ones (C20 and C22), which are called polyunsaturated fatty acids (PUFAs). These compounds are called essential because they are not metabolized by the animals, and their precursors are supplied in the diet (Bell, 1995). Additionally, PUFAs are being widely used by food industry in order to obtain fortified foods because these fatty acids belong to the omega- 3 family, besides the fact that these compounds are in the form of esters.

This fact demonstrates the need to obtain concentrates of natural sources of greater accessibility to the human body. Among other benefits, the omega-3 fatty acids represent alternative sources of production for functional food that help protect cell membranes, promoting the better functioning of the brain and eyes (Rubio-Rodríguez et al., 2010; Swanson et al., 2012). For adults, DHA is involved in maintaining normal function of brain and nervous system (Kuratko et al., 2013; Domenichiello et al., 2014).

Studies have been conducted on the EPA and DHA from fish oil fractionation and fortified foods have been correlated with health benefits, including cardiovascular protective effects, such as anti-arrhythmic, anti-thrombotic, anti-inflammatory, antihypertensive and anti-hyperlipidemic (González-Sarrías et al., 2013). They may also inhibit carcinogenesis, delay tumor growth. There is a need and commercial interest in investing in more research to obtain essential fatty acids EPA and DHA for the use of its potential application in the food and pharmaceutical

*Corresponding author: veravnascimento@gmail.com 
industries, with a view that these fatty acids play an important role in the prevention of human diseases.

Furthermore, the use of these fatty acids are discarded as waste from industrial processes, but they could be used as byproducts in relation to the use of fish oil as an economical low-cost alternative to reducing problems of disposal and environmental pollution (Rai et al., 2013).

Several methods have been used to produce PUFA concentrates include urea complexation, supercritical fluid extraction, low temperature crystallization, molecule distillation, lipase concentration and chemical alcoholysis (Adeoti \& Hawboldt, 2014; Homayooni et al., 2014).

The chemical alcoholysis comprises a process of alcoholysis on esters using basic catalysis allows obtaining mixtures of esters, meaning that from a carboxylic acid and an alcohol in basic medium, the bonds of the molecules on the reactants are broken and new bonds are formed to generate products. The aim of this work was to produce unsaturated fatty acids from oil of industrialized fish residues through a process of differentiated chemical alcoholysis to obtain long-chain poly-unsaturated concentrates.

\section{Materials and methods}

\subsection{Obtention of fish oil}

The experiment was conducted at the Processes and Products Development Laboratory (PPDL) at Federal University of Ceará (UFC). The crude material used on the experiment was special fish oil (about $3 \mathrm{~L}$ ) obtained from heads and bones of fish of various species from Campestre Industry and Commerce of Vegetal Oil (São Bernardo do Campo, SP, Brazil). The samples were stored on amber glass bottles under refrigeration $\left(5^{\circ} \mathrm{C}\right)$, until the moment of the analysis.

\subsection{Refining of the special fish oil}

The refining of crude fish oil normally includes the processes of degumming, neutralization, drying, bleaching, deodorization and winterization (Crexi et al., 2010). In this study, the performed a semi-refining were included, the neutralization (chemical refining) and bleaching (physical refining) of the addition of activated clay, according to American Oil Chemists Society (2002).

For the neutralization process, oil samples $(100 \mathrm{~g})$ were mixed with solution of sodium hydroxide $(20 \% \mathrm{w} / \mathrm{w})$ with an excess amount of study ( $40 \%$ by weight) in relation the mass of free fatty acids in the sample. The process was performed under vacuum ( $260 \mathrm{mmHg}$ abs), and with vigorous stirring (250 rpm) at $60^{\circ} \mathrm{C}$ for $20 \mathrm{~min}$. After this time, stirring was ceased and the temperature rose to $80^{\circ} \mathrm{C}$, order to facilitate the separation of oil and soapstock. The mixture is cooled and the separated oily fraction by centrifugation for $20 \mathrm{~min}$. The acidity content was used to evaluate the performance of the amount of sodium hydroxide added in excess in the neutralized oil (American Oil Chemists Society, 2002).

Neutralized oil samples were subjected to bleaching. Bleaching was carried out with two types of bleaching earth:
Acid Activated clay (AA) and a mixture of AA plus activated carbon $(\mathrm{AC})(1 \% \mathrm{w} / \mathrm{w})$ at $80^{\circ} \mathrm{C}$ and under pressure of $700 \mathrm{mmHg}$ (American Oil Chemists Society, 2002).

\subsection{Physical-chemical characterization of refined and hydrolyzed fish oil}

The oils were characterized through physical-chemical parameters, according to American Oil Chemists Society (1995, 2002): acidity, peroxide, saponification, iodine and percentage of free fatty acids (\%FFA), according to Table 1, described below:

\subsection{Reaction of chemical alcoholysis}

The chemical alcoholysis (transesterification) is a reaction of an oil or fat with an alcohol (with or without a catalyst) to form esters and glycerol. Since the reaction is reversible, the excess of alcohol is used to shift the equilibrium towards the product side (Andrade et al., 2011; Ma \& Hanna, 1999). The resulting complete reaction of the chemical alcoholysis is as follows (Figure 1).

For chemical alcoholysis, $10 \mathrm{~g}$ of refined fish oil was used with the addition of antioxidant BHT (400 ppm) and solution of anhydrous ethyl alcohol with a $\mathrm{KOH}$ catalyst in a concentration of $22 \%$ in relation to the oil mass, and the oil: ethanol molar ratio was of 1:39.

The FFA was obtained through chemical hydrolysis after the end of the reaction, according to the procedure described by Wanasundara \& Shahidi (1998). The equal volume of distilled

Table 1. Oleochemical indices used for the special fish oil (various species).

\begin{tabular}{lcc}
\hline \multicolumn{1}{c}{ Index } & Unit & Method \\
\hline Acidity & $\mathrm{mgNaOH} / \mathrm{g}$ & AOCS cd $1 \mathrm{c}-85$ \\
\% Free fatty acid & $\mathrm{mg} \mathrm{of} \mathrm{oleic} \mathrm{acid} / 100 \mathrm{mg}$ & AOCS Ca $5 \mathrm{a}-406$ \\
Peroxide & $\mathrm{meq} \mathrm{O}_{2} / \mathrm{kg}$ & A.O.C.S. Cd $8-53$ \\
Saponification & $\mathrm{mg} \mathrm{KOH} / \mathrm{g}$ & AOCS Cd 3-25 \\
Iodine & $\mathrm{g} \mathrm{I}_{2} / 100 \mathrm{~g}$ & AOCS $1 \mathrm{~b}-87$ \\
Refraction & & AOCS Cc $7-25$ \\
\hline
\end{tabular}

Source: Nascimento (2014)
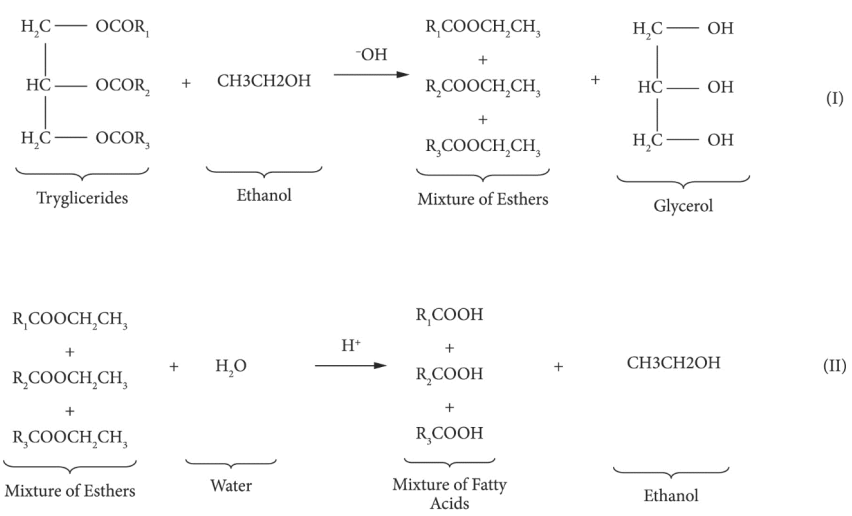

Figure 1. Complete reaction of alcoholysis of a triacylglyerol. Source: (I) Geris et al. (2007); Crexi et al. (2012); (II) Nascimento (2014). 
water was added to the saponified mixture in relation to the initial oil mass. Hexane was also added to the reaction mixture (twice the volume of hexane in relation to the initial oil mass) in order to extract the unsaponifiable matter and discard it. This procedure was performed twice. The fatty acids were extracted with hexane (equal volume in relation to the initial amount of oil) and the mixture was transferred into a separation funnel. The excess of solvent was removed at $40^{\circ} \mathrm{C}$ under a vacuum and FFA were stored at a freezing temperature $\left(-5^{\circ} \mathrm{C}\right)($ Crexi et al., 2012).

\subsection{Obtention of fatty acid profile through derivatization method for gas chromatography}

\section{Esterification of lipids}

The fatty acids were converted to fatty acid methyl esters (FAMEs) following the method of Hartman \& Lago (1973). FAMEs were analyzed by gas chromatography in Shimadzu model GC2010 equipped with a flame ionization detector and a capillary column (SP2560) of stationary phase biscianopropil polydimethylsiloxane $(100 \mathrm{~m} \times 0.25 \mathrm{~mm}$, df 0:20 $\mu \mathrm{m}$, Supelco Bellefonte, PA). The gas flow rates (White Martins) used were $1.4 \mathrm{~mL} \min ^{1}$ carrier gas $\left(\mathrm{H}_{2}\right), 1.5 \mathrm{~mL} \mathrm{~min}^{-1}$ make-up gas $\left(\mathrm{N}_{2}\right)$, and 30 and $300 \mathrm{~mL} \mathrm{~min}^{-1}$ flame gases, $\mathrm{H}_{2}$ and flame synthetic air, respectively. The sample injection rate (split) was $1 / 30$. The injector and detector temperatures were $220^{\circ} \mathrm{C}$. The column temperature was programmed to $80^{\circ} \mathrm{C}$ for $4 \mathrm{~min}$, followed by a ramp of $11^{\circ} \mathrm{C} \mathrm{min}^{-1}$ up to $180^{\circ} \mathrm{C}$, which was kept for $12 \mathrm{~min}$. A second ramp of $5^{\circ} \mathrm{C} \mathrm{min}^{-1}$ was run up to $220^{\circ} \mathrm{C}$ for $19 \mathrm{~min}$. The total analysis time was $40 \mathrm{~min}$. The FAME were identified by direct comparison of their retention times with standards (MIX-CRM47885), and were quantified as the percentage area of each FAME mixture.

\subsection{Statistical analysis}

The results for the yield and the oleochemical indices were expressed as means \pm SD $(n=5)$. Statistical evaluation was determined by analysis of variance (ANOVA) followed by comparison with the Tukey test. Statistical significance was set at $5 \%$. The programs used to perform the statistical analysis were Microsoft Excel 2007 and Minitab 17 Statistical Software.

\section{Results and discussion}

\subsection{Physical-chemical characterization}

The samples of crude fish oil showed significant differences in their oleochemical indices after refining treatment. The analyzed values of refined oil were lower than crude oil to percentage of free fatty acids (\%FFA), acidity, iodine and saponification. However, significant higher values for all the indices were recorded after hydrolysis reaction of the oil.

This process resulted in the production of fatty acids by hydrolysis from the triglyceride molecules in a chemical transformation to form poly-unsaturated organic molecules (Harris, 1981; Mill \& Mabey, 1988).

According with Erickson (1995), the quality of the raw material originated from the lipid residues of fish is critical to meet the quality parameters of the oleochemical indices (iodine index, saponification, peroxide of crude and refined samples), described on Table 2, which showed similar values to each other.

In Table 2 it is observed that there was a significant difference $(\mathrm{p}<0.05)$ between the crude, refined and hydrolyzed oils in the processes. It can also be verified that there was an increase in FFA values of the hydrolyzed fish oil.

The indices of crude oil determined in this study were lower than those found by Morais et al. (2001) with iodine, FFA and saponification values of 141.5, 5.2 and 186, respectively. Regarding the oleochemical indices of the refined oil samples found in these experiments were significantly lower than those found by Cunha et al. (2009), except for the saponification and peroxide index with 186 and 2.7, respectively (Cunha et al., 2009).

In this present study, the iodine value of crude, refined and hydrolyzed fish oil were 117.7, 119, $93.92 \mathrm{~g} \mathrm{I} / 100 \mathrm{~g}$, respectively. Oils are classified as drying, semi drying and non-drying on the basis of iodine value. Oils with an iodine value above $125 \mathrm{~g} \mathrm{I} / 100 \mathrm{~g}$ are classified as drying oils; those with iodine value between 110 and $140 \mathrm{~g} \mathrm{I} / 100 \mathrm{~g}$ are classified as semidrying oils and those with iodine value less than $110 \mathrm{~g} \mathrm{I} / 100 \mathrm{~g}$ are considered as nondrying oils (Ibeto et al., 2012). The characterized fish oils through different process were semidrying oils except hydrolyzed oil which was nondrying oil.

In relation acidity and peroxide levels of crude, refined and hydrolyzed fish oil were founded 5.4, 1.9, $11.72 \mathrm{mgNaOH} / \mathrm{g}$ and $3.3,2.7,7.22 \mathrm{mEq} \mathrm{O}_{2} / \mathrm{kg}$, respectively. The high acid and peroxide content evaluated in the sample hydrolyzed oil studied is possibly relationed with removal of the molecules glycerin (glycerol), which were attached to the molecules of fatty acids prior to the hydrolysis process.

\subsection{Fatty acids methyl profile from oil of special fish wast}

Table 3 presented the profile of essential fatty acids $n-3$ following the chemical alcoholysis process, which showed considerable amounts of $19.73 \%$, in particular, $9.12 \%$ of docosahexaenoic acid (DHA), $10.36 \%$ of eicosapentaenoic acid (EPA), 32.78\% of PUFAs, $30.59 \%$ of monounsaturated fatty acids (MUFAs), to the saturated fatty acids (SFA) the value was of $31.63 \%$. These values were similar to those obtained by Al-Souti et al. (2012) in fish oil, which was $8.5 \%$ of C22:6n-3 (DHA), 32.5\% of PUFAs, $21.7 \%$ of SFA, $14.6 \%$ of $n-3$ and $19.7 \%$ of $n-6$, with the exception of C20:5n-3 (EPA), which was only $5.5 \%$.

Table 2. Oleochemical indices of oil from industrialized fish residue on the crude, refined and hydrolyzed forms. ${ }^{\star}$

\begin{tabular}{lrcc}
\hline Oleochemical index & \multicolumn{1}{c}{ Crude fish } & Refined fish & Hydrolyzed fish \\
\hline \% FFA & $4.4^{\mathrm{b}} \pm 0.1$ & $1.6^{\mathrm{c}} \pm 0.01$ & $96.11^{\mathrm{a}} \pm 0.5$ \\
A.I. $(\mathrm{mgNaOH} / \mathrm{g})$ & $5.4^{\mathrm{b}} \pm 0.1$ & $1.9^{\mathrm{c}} \pm 0.01$ & $11.72^{\mathrm{a}} \pm 0.1$ \\
P.I. $(\mathrm{mEq} \mathrm{O} / \mathrm{kg})$ & $3.3^{\mathrm{b}} \pm 1.1$ & $2.7^{\mathrm{b}} \pm 0.1$ & $7.22^{\mathrm{a}} \pm 1.1$ \\
I.I. $\left(\mathrm{g} \mathrm{I}_{2} / 100 \mathrm{~g}\right)$ & $117.7^{\mathrm{a}} \pm 0.2$ & $119^{\mathrm{b}} \pm 1.2$ & $93.92^{\mathrm{c}} \pm 0.7$ \\
S.I. $(\mathrm{mg} \mathrm{KOH} / \mathrm{g})$ & $174.9^{\mathrm{b}} \pm 1.9$ & $212^{\mathrm{a}} \pm 0.8$ & $111.2^{\mathrm{c}} \pm 0.7$ \\
\hline
\end{tabular}

${ }^{\star}$ Data are means $\pm \mathrm{SD}(n=5)$. Letters with different superscripts on the same line are significant different for a confidence level of $95 \%$. \% FFA: percentage of free fatty acids; A.I.: acidity index; P.I.: peroxide index; I.I.: iodine index; S.I.: saponification index. Source: Nascimento (2014). 
Table 3. Fatty acid profiles of hydrolyzed and refined fish oils through derivatization method for gas chromatography.

\begin{tabular}{lcc}
\hline \multicolumn{1}{c}{ Fatty Acid } & Hydrolized oil & Refined oil \\
\hline C14:0 & $6.33^{\mathrm{a}} \pm 0.09$ & $5.96^{\mathrm{b}} \pm 0.0$ \\
C16:0 & $19.67^{\mathrm{a}} \pm 0.16$ & $17.22^{\mathrm{b}} \pm 0.01$ \\
C17:0 & $0.72^{\mathrm{a}} \pm 0.0$ & $0.62^{\mathrm{a}} \pm 0.09$ \\
C18:0 & $4.91^{\mathrm{a}} \pm 0.0$ & $0.87^{\mathrm{b}} \pm 0.01$ \\
Total SFA & 31.63 & 24.67 \\
C16:1n -7 & $5.77^{\mathrm{a}} \pm 0.03$ & $5.95^{\mathrm{a}} \pm 0.09$ \\
C18:1n -9 & $12.65^{\mathrm{a}} \pm 0.01$ & $7.09^{\mathrm{a}} \pm 0.01$ \\
C20:1n-9 & $1.96^{\mathrm{a}} \pm 0.0$ & $0.96^{\mathrm{b}} \pm 0.0$ \\
C24:1n -9 & $10.21^{\mathrm{a}} \pm 0.09$ & $6.06^{\mathrm{a}} \pm 8.05$ \\
Total MUFA & 30.59 & 20.06 \\
C18:2n -6 & $0.20^{\mathrm{b}} \pm 0.0$ & $0.3^{\mathrm{a}} \pm 0.0$ \\
C18:3n -6 & $2.0^{\mathrm{a}} \pm 0.0$ & $0.28^{\mathrm{b}} \pm 0.0$ \\
C18:3n -3 & $0.2^{\mathrm{b}} \pm 0.0$ & $0.22^{\mathrm{a}} \pm 0.0$ \\
C20:2n -6 & $0.14^{\mathrm{a}} \pm 0.0$ & $1.26^{\mathrm{a}} \pm 1.52$ \\
C20:3n -3 & $0.05^{\mathrm{b}} \pm 0.0$ & $0.15^{\mathrm{a}} \pm 0.0$ \\
C20:3n -6 & $0.06^{\mathrm{b}} \pm 0.0$ & $0,17^{\mathrm{a}} \pm 0.0$ \\
C20:4n -6 (AA) & $10.21^{\mathrm{a}} \pm 0.09$ & $0.61^{\mathrm{b}} \pm 0.84$ \\
C20:5n -3 (EPA) & $10.36^{\mathrm{a}} \pm 0.04$ & $5.87^{\mathrm{a}} \pm 8.28$ \\
C22:2n -6 & $0.44^{\mathrm{a}} \pm 0.0$ & $0.28^{\mathrm{a}} \pm 0.35$ \\
C22:6n -3 (DHA) & $9.12^{\mathrm{b}} \pm 0.07$ & $10.3^{\mathrm{a}} \pm 0.01$ \\
Total PUFA & 32.78 & 19.44 \\
\hline
\end{tabular}

${ }^{*}$ SFA (Saturated fatty acids); MUFA (Monounsaturated fatty acids); PUFAS (Polyunsaturated fatty acids). Values in the same row labeled with a different superscript letter are significantly different $(\mathrm{p}<0.05)$. Source: Nascimento (2014).

It is considered that the profiles of methyl fatty acids from residues of refined special fish oil and hydrolyzed special fish oil were significant different $(\mathrm{p}<0.05)$ for the two refining processes and hydrolysis, the latter with the highest amount of polyunsaturated. The main quantities of the following fatty acids were identified: saturated fatty acids C16:0 (palmitic acid), monounsaturated fatty acid (MUFA) and PUFAs (C18:1n-9 or oleic acid, C20:5n3 or EPA, C22:6n3 or DHA and C20:4n-6 or arachidonic), whose characterization was assigned to freshwater fish oil (Guler et al., 2008; Crexi et al., 2010). The most abundant fatty acids were arachidonic, eicosapentaenoic, docosahexaenoic and oleic acid. The hydrolyzed oil showed a higher concentration of PUFAs (32.78\%) than refined oil (19.44\%).

Simopoulos (2002) determined the ratio of fatty acids $n-6 / n-3$ and concluded that the values ranged from 1 to $1 / 5$ and that systemic degenerative diseases had reduced, highlighting the importance of considering this data as a parameter of evaluation of lipid nutrition with these types of fatty acids ingested in food.

Figure 2 shows a chromatogram of the hydrolyzed oil from industrialized fish residue showing the existence of concentrates of EPA (C20:5n-3) and DHA (C22:6n-3) after alcoholysis. According to Padilha \& Augusto-Ruiz (2007), the industrial fish oil is generally obtained by hydrothermal process from pelagic species, so its composition varies according to species and even, according to season, sex, reproductive cycle, among other factors. Pelagic fish, due to its habitation condition and formation of large fish shoal, are of great industrial importance

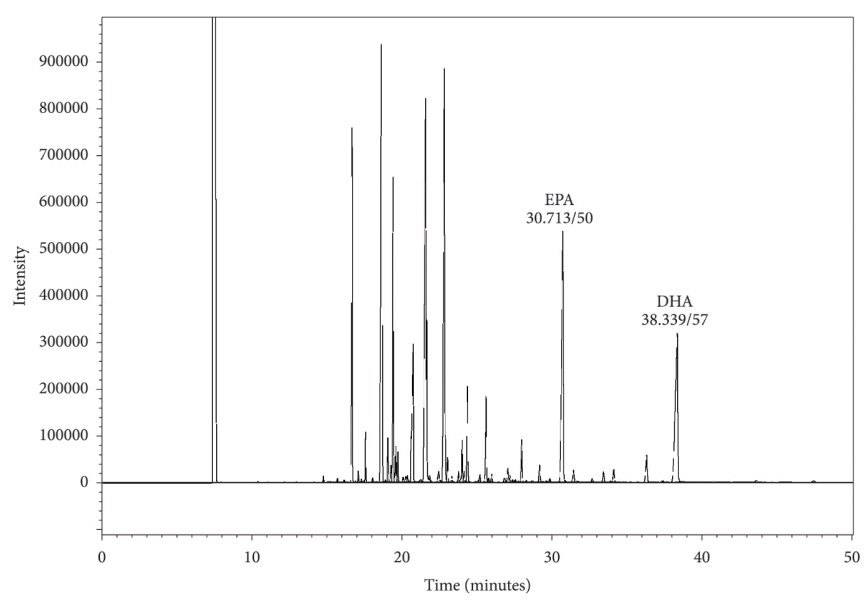

Figure 2. Identification of polyunsaturated fatty acids (PUFA): eicosapentaenoic (EPA) and Docosahexaenoic (DHA). Source: Nascimento (2014).

and seem to be the best sources of EPA and DHA (Gonçalves \& Souza-Soares, 2000).

\section{Conclusions}

It was concluded that the processes adopted in refining treatments of crude fish oil were satisfactory after physicalchemical analysis. The same happened after the hydrolysis of the oil, where the concentration of polyunsaturated fatty acids (PUFAs) have been preserved with a percentage of $32.78 \%$ compared to $19.44 \%$ of PUFAs from refined fish oil, a difference of $13.34 \%$, which proves the efficiency of this process as the main stage for obtaining the esters of fatty acids. The chemical composition was significant with $32.78 \%$ of unsaturated fatty acids, enabling the industrial development of new alternative coproducts in beneficial to the demand of nutraceutical production and fortified foods.

\section{References}

Adeoti, I. A., \& Hawboldt, K. (2014). A review of lipid extraction from fish processing by-product for use as biofuel. Biomass and Bioenergy, 63, 330-340. http://dx.doi.org/10.1016/j.biombioe.2014.02.011.

Al-Souti, A., Al-Sabahi, J., Soussi, B., \& Goddard, S. (2012). The effects of fish oil-enriched diets on growth, feed conversion and fatty acid content of red hybrid tilapia, Oreochromis sp. Food Chemistry, 133, 723-727.

American Oil Chemists Society - AOCS. (1995). Official Methods and Recommended Pratices of the American Oil Chemists' Society (4th ed.). Washington.

American Oil Chemists Society - AOCS. (2002). Official Methods and Recommended Pratices of the American Oil Chemists' Society (5th ed.). Washington.

Andrade, J. E., Pérez, A., Sebastian, P. J., \& Eapen, D. (2011). Retraction notice to "A Review of Biodiesel Production Processes". Biomass Bioenergy, 35, 1008-1020.

Bell, A. W. (1995). Regulation of organic nutrient metabolism during transition from late pregnancy to early lactation. Journal Animal Science, 73, 2804-2819. 
Benites, C. I., \& Souza-Soares, L. A. (2010). Farinhas de silagem de resíduo de pescado co-secas com farelo de arroz: uma alternativa viável. Arquivos de Zootecnia, 59, 447-450.

Chowdhury, R., Stevens, S., Gorman, D., Pan, A., Warnakula, S., Chowdhury, S., Ward, H., Johnson, L., Crowe, F., Hu, F. B., \& Franco, O. H. (2012). Association between fish consumption, long chain omega 3 fatty acids, and risk of cerebrovascular disease: systematic review and meta-analysis. British Medical Journal, 345, e6698. http:// dx.doi.org/10.1136/bmj.e6698. PMid:23112118

Corrêa, A. P. A. (2008). Fracionamento de óleo de peixe com dióxido de carbono supercrítico (Dissertação de mestrado em Engenharia de Alimentos). Fundação da Universidade Federal do Rio Grande do Sul, Porto Alegre.

Crexi, V. T., Monte, M. L., Soares, L. A. S., \& Pinto, L. A. A. (2010). Production and refinement of oil from carp (Cyprinus carpio) viscera. Food Chemistry, 119(3), 945-950. http://dx.doi.org/10.1016/j. foodchem.2009.07.050.

Crexi, V. T., Monte, M. L., Monte, M. L., \& Pinto, L. A. A. (2012). Polyunsaturated fatty acid concentrates of carp oil: chemical hydrolysis and urea complexation. Journal of the American Oil Chemists' Society, 89(2), 329-334. http://dx.doi.org/10.1007/s11746-011-1899-4.

Cunha, D. C., Crexi, V. T., \& Pinto, L. A. A. (2009). "Winteracão" de óleo de pescado via solvente. Ciência e Tecnologia de Alimentos, 29, 207-213.

Domenichiello, A. F., Chen, C. T., Trepanier, M. O., Stavro, P. M., \& Bazinet, R. P. (2014). Whole body synthesis rates of DHA from $\alpha$-linolenic acid are greater than brain DHA accretion and uptake rates in adult rats. Journal of Lipid Research, 55(1), 62-74. http:// dx.doi.org/10.1194/jlr.M042275. PMid:24212299

Erickson, D. R. (1995). Practical handbook of soybean processing and utilization. Champaign: AOCS Press.

Geris, R., Santos, N., Amaral, B., Maia, I., Castro, V., \& Carvalho, J. R. M. (2007). Reação de Transesterificação para Aulas Práticas de Química Orgânica. Quimica Nova, 30(5), 1369-1373. http://dx.doi. org/10.1590/S0100-40422007000500053.

Gonçalves, A. A., \& Souza-Soares, L. A. (2000). Efeitos do processamento e armazenamento na fração lipídica do pescado. Vetor, 10, 93-112.

González-Sarrías, A., Larrosa, M., García-Conesa, M. T., Tomás-Barberán, F. A., \& Espín, J. C. (2013). Nutraceuticals for older people: facts, fictions and gaps in knowledge. Maturitas, 75(4), 313-334. http:// dx.doi.org/10.1016/j.maturitas.2013.05.006. PMid:23791247

Guler, G. O., Kiztanir, B., Aktumsek, A., Citil, O. B., \& Ozparlak, H. (2008). Determination of the seasonal changes on total fatty acid composition and $\omega 3 / \omega 6$ ratios of carp (Cyprinus carpio L.) muscle lipids in Beysehir Lake (Turkey). Food Chemistry, 108(2), 689-694. http://dx.doi.org/10.1016/j.foodchem.2007.10.080.

Harris, J. C. (1981). Rate of hydrolysis. In Handbook of chemical property estimation methods: enviromental behavior of organic compounds (pp. 7-48). New York: Mc Graw-Hill.
Hartman, L., \& Lago, R. C. A. (1973). Rapide preparation of fatty acid methyl esters from lipid. Laboratory Practices, 22, 474-477.

Homayooni, B., Sahari, M. A., \& Barzegar, M. (2014). Concentrations of omega-3 fatty acids from rainbow sardine fish oil by various methods. International Food Research Journal, 21, 743-748.

Ibeto, C. N., Okoye, C. O. B., \& Ofoefule, A. U. (2012). Comparative study of the physicochemical characterization of some oils as potential feedstock for biodiesel production. ISRN Renewable Energy, 2012, 1-5.

Kuratko, C. N., Barrett, E. C., Nelson, E. B., \& Salem, N. Jr. (2013). The relationship of docosahexaenoic acid (DHA) with learning and behavior in healthy children: a review. Nutrients, 5(7), 2777-2810. http://dx.doi.org/10.3390/nu5072777. PMid:23877090

Ma, F., \& Hanna, M. A. (1999). Biodiesel production: a review. Bioresource Technology, 70(1), 1-15. http://dx.doi.org/10.1016/ S0960-8524(99)00025-5.

Mill, T., \& Mabey, W. (1988). Hydrolysis of organic chemicals in the Handbook of Enviromental Chemistry (2nd ed.). New York: Springer-Verlag.

Morais, M. M., Crexi, V. T., Pinto, L. A. A., Ortiz, S. C. A., Silva, R. L., \& Silva, J. (2001). Estudo do Processo de Refino do Óleo de Pescado. Revista do Instituto Adolfo Lutz, 60, 23-33.

Nascimento, V. L. V. (2014). Desenvolvimento de processos químicos para síntese de ésteres poli-insaturados (Tese de doutorado em Biotecnologia). Laboratório de Desenvolvimento de Processos e Produtos - LDPP, PADETEC, Universidade Federal do Ceará, Fortaleza.

Padilha, M. E. S., \& Augusto-Ruiz, W. (2007). Hidrólise enzimática do óleo de pescado. Food Science and Technology, 27(2), 285-290. http://dx.doi.org/10.1590/S0101-20612007000200013.

Rai, A. K., Bhaskar, N., \& Baskaran, V. (2013). Bioefficacy of EPADHA from lipids recovered from fish processing wastes through biotechnological approaches. Food Chemistry, 136(1), 80-86. http:// dx.doi.org/10.1016/j.foodchem.2012.07.103. PMid:23017395

Rubio-Rodríguez, N., Beltrán, S., Jaime, I., Diego, S. M., Sanz, M. T., \& Rovira, C. J. (2010). Production of omega-3 polyunsaturated fatty acid concentrates: A review. Innovative Food Science \& Emerging Technologies, 11(1), 1-12. http://dx.doi.org/10.1016/j.ifset.2009.10.006.

Simopoulos, A. P. (2002). Omega-3 fatty acids in inflammation and autoimmune diseases. Journal of the American College of Nutrition, 21(6), 495-505. http://dx.doi.org/10.1080/07315724.2002.1071924 8. PMid:12480795

Swanson, D., Block, R., \& Mousa, S. A. (2012). Omega-3 fatty acids EPA and DHA: health benefits throughout life. Advances In Nutrition, 3(1), 1-7. http://dx.doi.org/10.3945/an.111.000893. PMid:22332096

Wanasundara, U. N., \& Shahidi, F. (1998). Antioxidant and pro-oxidant activity of green tea extracts in marine oils. Food Chemistry, 63(3), 335-342. http://dx.doi.org/10.1016/S0308-8146(98)00025-9. 